\author{
Jerzy Szukalski \\ Wyższa Szkoła Stosunków Międzynarodowych \\ i Komunikacji Społecznej w Chetmie
}

\title{
EWOLUCJA POZYCJI USTROJOWEJ PREZYDENTA UZBEKISTANU W LATACH 1990-2015
}

Uzbekistan stanowi interesujący przykład transformacji ustrojowej na obszarze Azji Centralnej, gdzie cechy typowe dla całego obszaru poradzieckiego splotły się z uwarunkowaniami endemicznymi, a ściślej z aksjologią i normami trybalizmu. Pierestrojka i rozpad Związku Radzieckiego umożliwiły Uzbekistanowi odzyskanie niepodległości w $1991 \mathrm{r}$. oraz rozpoczęcie procesu gruntownych przeobrażeń ustrojowych w republice, których celem - przynajmniej deklaratywnym - było zbudowanie demokratycznego państwa prawnego, opartego na wzorcach demokracji Europy Zachodniej. Efektem przeobrażeń było pojawienie się w państwie nowych instytucji, charakterystycznych dla państw demokratycznych. Jedną z nich była instytucja Prezydenta Uzbekistanu. Pozycja ustrojowa prezydenta w niepodległym Uzbekistanie kształtowała się w burzliwym okresie przemian i ścierania się różnych koncepcji ustrojowych oraz interesów lokalnych i klanowych.

Analiza ewolucji pozycji ustrojowej Prezydenta Uzbekistanu będąca przedmiotem opracowania wymaga omówienia zarówno normatywnych elementów określających tę pozycję, tzn. konstytucyjnej zasady podziału władz, charakteru mandatu prezydenta, zasad jego odpowiedzialności, funkcji i zadań prezydenta oraz ich rozwinięcia wyrażonego w zakresie przyznanych mu kompetencji, jak również czynników pozanormatywnych, które niezależnie od regulacji konstytucyjnych decydują o rzeczywistej pozycji ustrojowej każdego prezydenta. W tym ostatnim aspekcie należy wskazać na indywidualne cechy osobowości głowy państwa, posiadane predyspozycje, a także uwarunkowania endemiczne oraz system polityczny państwa, który w praktyce życia politycznego nie zawsze odpowiada regulacjom konstytucyjnym.

W opracowaniu przyjęto układ chronologiczno-rzeczowy.

1. Pierestrojka w Związku Radzieckim stała się impulsem do początkowo nieśmiałych przemian w republikach związkowych i autonomicznych, które w literaturze przedmiotu określano jako liberalizację istniejącego systemu totalitarnego. W Uzbeckiej Socjalistycznej Republice Radzieckiej (Uzbeckiej SRR) proces ten 
rozpoczął się jesienią 1989 r. i odbywał się pod „kontrolą" nomenklatury komunistycznej, której przewodził I sekretarz Komitetu Centralnego Komunistycznej Partii Uzbeckiej SRR - Isłam Karimow. Wyrazem zachodzących przemian było przyjęcie przez Radę Najwyższą Uzbeckiej SRR w dniu 20 października 1989 r. ustawy o zmianach i uzupełnieniach konstytucji oraz ustawy o wyborach deputowanych ludowych. W następnym dniu przyjęto ustawę nadającą językowi uzbeckiemu status języka państwowego. Kolejną istotną zmianą było wprowadzenie urzędu prezydenta w dniu 24 marca 1990 r. i wybranie na ten urząd w tym samym dniu przez Radę Najwyższą (RN) Isłama Karimowa. Z kolei w dniu 18 lutego 1990 r. odbyły się pierwsze częściowo wolne wybory do republikańskiej RN, która już w nowym składzie uchwaliła w dniu 20 czerwca tegoż roku Deklarację o suwerenności. Nieudany pucz moskiewski w dniach 19-22 sierpnia 1991 r. przyspieszył proklamowanie przez RN Uzbeckiej SRR niepodległości, co nastąpiło w dniu 31 sierpnia, a następnie dnia 1 września w formie przyjęcia ustawy o podstawach niepodległości państwowej Republiki Uzbekistanu. Wyrazem odrębności państwowej Republiki Uzbekistanu (RU) było przyjęcie własnych symboli narodowych, tzn. flagi, godła i hymnu' ${ }^{1}$.

2. Urząd Prezydenta RU jest nową instytucją prawnoustrojową, którą wprowadziła nowelizacja Konstytucji Uzbeckiej SRR z dnia 24 marca 1990 r. ${ }^{2}$ Uzbekistan posiada jednak długie tradycje silnego przywództwa głowy państwa. Od czasów starożytnych rolę tę pełnili zmieniający się monarchowie różnych dynastii władających terytorium współczesnego Uzbekistanu, a w czasach radzieckich rolę tę pełniło kolegialne ciało, jakim było Prezydium Rady Najwyższej Uzbeckiej SRR, zaś w szczególności uosabiał je przewodniczący Rady Najwyższej Uzbeckiej SRR ${ }^{3}$. W okresie radzieckim w myśl zasady jedności władzy państwowej najwyższym organem władzy państwowej Związku Radzieckiego była Rada Najwyższa ZSRR, co wyrażał art. 108 ust. 1 Konstytucji ZSRR z 1977 r. Podobnie było w republikach związkowych, których konstytucje były odwzorowaniem radzieckiej ustawy zasadniczej. W Uzbeckiej SRR art. 101 jej Konstytucji z dnia 19 kwietnia 1978 r. stanowił, że „Najwyższym organem władzy państwowej Uzbeckiej SRR jest Rada Najwyższa Uzbeckiej SRR”. Sprawowanie funkcji głowy państwa w ramach republiki związkowej zostało powierzone Prezydium Rady Najwyższej Uzbeckiej SRR, która była organem kolegialnym wyłanianym przez Radę Najwyższą Uzbeckiej SRR z grona jej członków. W okresie między sesjami Rady Najwyższej to Prezydium przejmowało wszystkie

1 T. Bodio, T. Mołdawa, Konstytucje państw Azji Centralnej: tradycje i współczesność, Warszawa 2007, s. 485-489; M. Sajnog, Republika Uzbekistanu, (w:) W. Baluk, A. Czajowski (red.), Ustroje polityczne krajów Wspólnoty Niepodległych Państw, Wrocław 2007, s. 310-311; A. Kh. Saidov, K. A. Wojtaszczyk, Konstytucyjne podstawy ustroju państwa, (w:) T. Bodio (red.), Uzbekistan: historia - społeczeństwo - polityka, Warszawa 2001, s. 129.

2 Zakon Uzbiekskoj SSR nr 4-XII ot 24 marta 1990 goda Ob uczrieżdieniji posta Priezidienta Riespubliki Uzbiekistan i wniesieniji izmienienij i dopołnienij w Konstituciju (Osnownoj zakon) Riespubliki Uzbiekistan, http://www. parliament.gov.uz/ru/law/1990/2800/ (data dostępu: 11.06.2015 r.).

3 T. Bodio, T. Mołdawa, Konstytucje państw..., op. cit., s. 487; Priess-Służba Priezidienta Riespubliki Uzbiekistan, Biografija, http://www.press-service.uz/\#ru/content/glava_gosudarstwa/biografiya/ (data dostępu: 11.06.2015 r.). 
jej zadania, włącznie z kompetencjami o charakterze reprezentacyjnym ${ }^{4}$. W znowelizowanej Konstytucji Uzbeckiej SRR Prezydent został określony jako „najwyższy urzędnik Uzbeckiej SRR”. Takie określenie pozycji ustrojowej Prezydenta było bardzo niejednoznaczne. Konstytucja nie przyznała mu bowiem funkcji głowy państwa i w dalszym ciągu uprawnienia reprezentacyjne przysługiwały formalnie Prezydium Rady Najwyższej.

3. Znaczące wzmocnienie pozycji ustrojowej Prezydenta Uzbekistanu i skonkretyzowanie jego funkcji ustrojowych przyniosła dopiero nowelizacja Konstytucji Uzbeckiej SRR, przyjęta w dniu 1 listopada 1990 r. Wprowadziła ona istotne zmiany w dotychczasowej organizacji naczelnych organów republiki. Przede wszystkim nastąpiło wzmocnienie władzy wykonawczej. W miejsce dotychczasowej Rady Ministrów Uzbeckiej SRR utworzono bowiem Gabinet Ministrów pod przewodnictwem Prezydenta, który został szefem władzy wykonawczej. Gabinet Ministrów podlegał jednak nadal wyłącznie Radzie Najwyższej i ponosił przed nią odpowiedzialność, ponieważ system organów Uzbeckiej SRR był w dalszym ciągu ukształtowany na zasadzie jednolitości władzy. W tym miejscu należy podkreślić, że wprowadzony przez znowelizowaną Konstytucję podział władzy na ustawodawczą, wykonawczą i sądowniczą miał na tym etapie przeobrażeń ustrojowych w republice wymiar jedynie deklaratywny. W związku z utworzeniem Gabinetu Ministrów zespolono kancelarie (aparaty) Rady Ministrów i Prezydenta w jednolity organ - Kancelarię przy Prezydencie Uzbeckiej SRR. Ponadto utworzono urząd Wiceprezydenta RU. Był on mianowany przez Prezydenta i musiał uzyskać zatwierdzenie ze strony Rady Najwyższej Uzbeckiej SRR. Z polecenia Prezydenta, Wiceprezydent miał kierować Gabinetem Ministrów i organizować jego pracę 5 .

W znowelizowanej Konstytucji Uzbeckiej SRR pozycję ustrojową Prezydenta określił - przynajmniej formalnie - art. 118-1, który stanowił, że „Prezydent Uzbeckiej SRR pełni najwyższą władzę wykonawczą i zarządzającą w Uzbeckiej SRR, jednocześnie jest on Przewodniczącym Gabinetu Ministrów”. W stosunku do rządu Prezydent mógł proponować jego skład personalny, który był zatwierdzany przez Radę Najwyższą. Prezydent zapewniał współdziałanie władzy wykonawczej i zarządzającej Uzbeckiej SRR, mógł tworzyć i likwidować ministerstwa oraz komitety państwowe, co wymagało jednak zatwierdzenia przez Radę Najwyższą. W razie sprzeczności z Konstytucją, ustawami, dekretami i rozporządzeniami Prezydenta aktów wydawanych przez ministerstwa, komitety państwowe i komitety wykonaw-

$4 \quad$ Zob. Konstitucija (Osnownoj Zakon) Uzbekskoj Sowietskoj Socjalisticzieskoj Riespubliki (prinjata na wnieoczieriednoj sziestoj siessiji Wierchownogo Sowieta Uzbekskoj SRR diewjatogo sozywa 19 aprielja 1978 goda), http:// zakonuz.uzshar.com/?document=5990 (data dostępu: 12.06 .2015 r.).

5 Zakon Uzbiekskoj Sowietskoj Socialisticzieskoj Riespubliki nr 156-XII ot 1 nojabrja 1990 goda O sowierszienstwowaniji struktury ispołnitiel'noj i rasporjaditiel'noj własti w Uzbiekskoj SSR i wniesieniji izmienienij i dopołnienij w Konstituciju (Osnownoj Zakon) Uzbiekskoj SSR, http://www.lex.uz/Pages/GetAct.aspx?lact_id=957016 (data dostępu: 12.06.2015 r.), art. 1-2. 
cze rad deputowanych ludowych, Prezydent mógł zawiesić ich wykonanie lub je zmienić.

W zakresie stosunków z Radą Najwyższą Prezydent otrzymał uprawnienia, które obejmowały: prawo inicjatywy ustawodawczej, podpisywanie ustaw i prawo weta zawieszającego. Ustawa zawetowana przez Prezydenta wymagała do jej przyjęcia większości $2 / 3$ głosów ogólnej liczby deputowanych Rady Najwyższej.

Odnośnie kompetencji kreacyjnych - Prezydent zgłaszał i przedstawiał Radzie Najwyższej kandydatury na stanowiska: przewodniczącego Komitetu Kontroli Państwowej Uzbeckiej SRR, przewodniczącego Sądu Najwyższego Uzbeckiej SRR, Głównego Arbitra Państwowego Uzbeckiej SRR, Prokuratora Uzbeckiej SRR i jego zastępców, przewodniczącego Komitetu Państwowego Uzbeckiej SRR ds. Ochrony Przyrody. Prezydent mógł również wnioskować o ich odwołanie, z wyjątkiem przewodniczącego Sądu Najwyższego. Ponadto rekomendował on w porozumieniu z przewodniczącymi rad deputowanych ludowych kandydatów na stanowiska przewodniczących komitetów wykonawczych tychże $\operatorname{rad}^{6}$.

W zakresie przyznanych Prezydentowi funkcji i kompetencji oraz „w celu wykonania Konstytucji Uzbeckiej SRR i ustaw Uzbeckiej SRR” mógł on wydawać dekrety i rozporządzenia ${ }^{7}$.

Konstytucja przewidywała możliwość przedterminowego zakończenia urzędowania przez Prezydenta, co zostało wyrażone w ogólnikowej formule art. 118-9: „Jeżeli Prezydent Uzbeckiej SRR z tych czy innych przyczyn nie mógł dalej wypełniać swoich obowiązków, wybory nowego Prezydenta Uzbeckiej SRR powinny być przeprowadzone w okresie trzymiesięcznym". W tym okresie obowiązki Prezydenta przejmował Wiceprezydent, a w razie niemożności - Przewodniczący Rady Najwyższej.

Od początku powstania urzędu Prezydenta Uzbekistanu zaznaczyła się silna jego personalizacja, co nie pozostało bez wpływu na dalsze zmiany w ustawie zasadniczej. Jednym z głównych celów tych zmian było zachowanie silnej władzy wykonawczej, reprezentowanej przede wszystkim przez Prezydenta. Już 18 listopada 1991 r. na mocy kolejnej nowelizacji ustawy zasadniczej nastąpiła likwidacja urzędu Wiceprezydenta RU. W dniu 29 grudnia 1991 r. odbyły się pierwsze powszechne wybory prezydenckie, które zostały połączone $\mathrm{z}$ referendum $\mathrm{w}$ sprawie niepodległości Uzbekistanu. Zdecydowanym faworytem wyborów był urzędujący prezydent Isłam Karimow, który otrzymał $86 \%$ głosów. Mandat uzyskany w wyborach powszechnych niewątpliwie wzmocnił pozycję ustrojową Prezydenta Uzbekistanu.

4. Dynamicznie zmieniająca się rzeczywistość polityczna niepodległego już Uzbekistanu wymagała opracowania zupełnie nowej konstytucji. Decyzja 
o rozpoczęciu prac nad jej projektem została podjęta jeszcze w marcu 1990 roku na I sesji RN Uzbeckiej SRR. W czerwcu powołano komisję konstytucyjną, której przewodniczącym został Isłam Karimow. Od początku prac nad projektem odegrał on decydującą rolę w procesie jego tworzenia. Ostateczna wersja projektu została przedstawiona w dniu 2 lipca 1992 roku na X sesji RN Uzbeckiej SRR. Publikacja projektu w dniu 26 września rozpoczęła ogólnonarodową debatę nad konstytucją republiki. W jej trakcie wprowadzono do ustawy zasadniczej jeszcze kilkadziesiąt zmian i uzupełnień ${ }^{8}$.

Konstytucja Uzbekistanu została uchwalona w dniu 8 grudnia 1992 roku na XI sesji Rady Najwyższej Uzbeckiej SRR z mocą obowiązującą od dnia jej przyjęcia. Ustawa zasadnicza składa się z preambuły, 6 rozdziałów, 26 podrozdziałów (tytułów) i 128 artykułów. Regulacje dotyczące Prezydenta RU znalazły się w rozdziale piątym, zatytułowanym „Organizacja władzy państwowej”. Rozdział ten składa się z 8 podrozdziałów i zawiera określenie systemu organów władzy państwowej, tzn. strukturę i kompetencje centralnych oraz lokalnych organów państwa. Władza państwowa została oparta na zasadzie podziału (art. 11), według którego władza ustawodawcza została powierzona Olij Madżlisowi, złożonemu z Izby Ustawodawczej i Senatu, wykonawcza - Prezydentowi i Gabinetowi Ministrów i sądownicza - sądom. Chociaż Konstytucja nie wskazała, czy trójdzielne władze są równorzędne, to z całokształtu regulacji konstytucyjnych wynika jednoznacznie, że przewagę posiada władza wykonawcza, uosabiana przede wszystkim przez Prezydenta.

Pozycja ustrojowa Prezydenta Uzbekistanu została określna w art. 89 i 93 ust. 1-3 Konstytucji z 1992 r. Przepisy te stanowiły, że Prezydent jest głową państwa i szefem władzy wykonawczej, zapewnia harmonijne funkcjonowanie i współdziałanie organów władzy państwowej, jest gwarantem suwerenności, bezpieczeństwa i integralności terytorialnej państwa, reprezentuje państwo w stosunkach wewnętrznych i międzynarodowych oraz gwarantuje przestrzeganie praw i wolności obywateli, Konstytucji i ustaw Republiki Uzbekistanu. Wskazane wyżej przepisy art. 89 i 93 ust. 1-3 Konstytucji określają nie tylko pozycję ustrojową Prezydenta Uzbekistanu, lecz również zawierają charakterystykę ogólnego zakresu przyznanych mu funkcji i zadań. Należy podkreślić, że w Konstytucji Uzbekistanu - w przeciwieństwie do ustaw zasadniczych wielu państw demokratycznych - nie ma właściwie przepisu, który mógłby ograniczyć zakres działań Prezydenta. Przykładowo w Konstytucji Rzeczypospolitej Polskiej taką formułę zawiera przepis art. 126 ust. 3, który stanowi, że „Prezydent Rzeczypospolitej wykonuje swoje zadania w zakresie i na zasadach określonych w Konstytucji i ustawach"9.

T. Bodio, T. Mołdawa, Konstytucje państw..., op. cit., s. 487-491; A. Kh. Saidov, K. A. Wojtaszczyk, Konstytucyjne podstawy..., op. cit., s. 129-131; Oficjalna strona internetowa Senatu Olij Madżlisu Republiki Uzbekistanu, Istorija razwitija parłamientarizma w Uzbiekistanie, http://www.senat.uz/ru/about/index.html (data dostępu: 14.06.2015 r.).

9 Vide: Konstytucja Rzeczypospolitej Polskiej z dnia 2 kwietnia 1997 r., Dz.U. z 1997 r. Nr 78, poz. 83 z później szymi zmianami (zm.: Dz.U. z 2001 r., Nr 28, poz. 319; z 2006 r., Nr 200, poz. 1471; z 2009 r., Nr 114, poz. 346), 
Istotnym wyznacznikiem pozycji ustrojowej Prezydenta Uzbekistanu - obok szerokiego zakresu jego kompetencji - jest brak możliwość jego odwołania, bowiem nie przewiduje tego Konstytucja. W istocie nie odpowiada on ani politycznie, ani konstytucyjnie. Ponadto pozycję ustrojową Prezydenta wzmacnia fakt, że po zakończeniu kadencji staje się on dożywotnim członkiem Senatu Olij Madżlisu Republiki Uzbekistanu, co oznacza przedłużenie chroniącego go immunitetu (art. 97).

Konstytucja z 1992 r. stanowi, że Prezydent jest wybierany na kadencję pięcioletnią w wyborach powszechnych, bezpośrednich, równych i w głosowaniu tajnym $^{10}$. O najwyższy urząd w państwie może się ubiegać obywatel Uzbekistanu po ukończeniu 35 lat, stale zamieszkujący na terytorium kraju przez okres co najmniej 10 lat przed wyborami oraz posiadający pełnię praw wyborczych. Ta sama osoba nie może pełnić funkcji głowy państwa przez więcej niż dwie kolejne kadencje (art. 90). Prezydentem zostaje kandydat, który otrzymał ponad połowę ważnie oddanych głosów. Natomiast w drugiej turze głosowania wystarcza już zwykła większość głosów oddanych na jednego z dwóch kandydatów, ubiegających się o urząd Prezydenta. Ważność wyboru stwierdza Centralna Komisja Wyborcza Republiki Uzbekistanu (CKW).

Objęcie urzędu przez Prezydenta następuje po złożeniu przez niego przysięgi przed Izbą Ustawodawczą i Senatem Olij Madżlisu, nie później jednak niż dwa miesiące od daty ogłoszenia przez CKW oficjalnych wyników wyborów prezydenckich. Urzędujący Prezydent kończy swoją kadencję w momencie objęcia urzędu przez nowo wybranego Prezydenta. Konstytucja określiła tylko jeden powód wcześniejszego zakończenia piastowania urzędu przez głowę państwa, a mianowicie ze względu na jego stan zdrowia, potwierdzony opinią Państwowej Komisji Lekarskiej powołanej decyzją obu izb parlamentu. W takiej sytuacji w ciągu 10 dni na wspólnym posiedzeniu Izby Ustawodawczej i Senatu Olij Madżlisu wybierana jest spośród deputowanych i senatorów na okres najdalej 3 miesięcy osoba, która tymczasowo pełni obowiązki Prezydenta. Konstytucja obliguje również w takim wypadku do przeprowadzenia w terminie trzech miesięcy nowych wyborów Prezydenta Uzbekistanu (art. 96). Ustawa zasadnicza nie przewiduje natomiast możliwości złożenia z urzędu Prezydenta poprzez zastosowanie procedury impeachmentu. Prezydent za swoją działalność nie ponosi bowiem ani odpowiedzialności politycznej, ani odpowiedzialności konstytucyjnej, co jest zresztą cechą charakterystyczną dla części państw Azji Centralnej - Kazachstanu i Turkmenistanu.

[w:] A. Flisek (red.), Teksty ustaw Becka. Prawo konstytucyjne, Warszawa 2015, s. 25.

10 Kadencję pięcioletnią Prezydenta Uzbekistanu wprowadzono dopiero na mocy nowelizacji Konstytucji z dnia 12 grudnia 2011 roku. W Konstytucji z 1992 roku kadencja Prezydenta wynosiła pięć lat, ale w wyniku referendum z 27 stycznia 2002 r. wydłużono ją do siedmiu lat, za czym miało się opowiedzieć $90 \%$ obywateli kraju. Zob. Zakon Riespubliki Uzbiekistan nr 3 RU-305 ot 12 diekabrja 2011 goda O wniesieniji poprawki w stat'ju 90 Konstituciji Riespubliki Uzbiekistan, http://www.lex.uz/pages/GetAct.aspx?lact_id=2216248\&ONDATE=28.12.2011\%20 00\#2216403 (data dostępu: 17.06.2015 r.), art. 1. 
Konstytucja zakazuje - zgodnie z zasadą incompatibilitas - łączenia urzędu Prezydenta RU z mandatem deputowanego, zajmowaniem jakichkolwiek innych płatnych funkcji czy stanowisk oraz prowadzeniem działalności gospodarczej (art. 91).

Po uzyskaniu przez Uzbekistan niepodległości w 1991 roku powszechne wybory prezydenckie były przeprowadzane w tym kraju czterokrotnie i każdorazowo Prezydenta wybierano już w pierwszej turze głosowania. Był nim zawsze ten sam kandydat - Isłam Karimow. Działo się tak, pomimo że w myśl uregulowań konstytucyjnych ,ta sama osoba nie może pełnić funkcji Prezydenta Republiki Uzbekistan więcej niż dwie kadencje pod rząd" (art. 90). W pierwszych wyborach prezydenckich, które odbyły się w dniu 29 grudnia 1991 roku Isłam Karimow otrzymał 86\% głosów. Jego jedyny kontrkandydat - Muhammad Solich zdobył wówczas 12,5\% głosów. W kolejnych wyborach, przeprowadzonych w dniu 9 stycznia 2000 roku według oficjalnych danych Isłam Karimow uzyskał 91,9\% głosów, dystansując miażdżącą przewagą ponownie tylko jedynego kontrkandydata M. Dżalałowa ${ }^{11}$. W trzecich z kolei wyborach prezydenckich w dniu 23 grudnia 2007 roku urzędujący Prezydent Uzbekistanu otrzymał 90,77\% głosów przy frekwencji wynoszącej 90,6\% uprawnionych do głosowania. W wyborach tych wystartowali jeszcze trzej inni kandydaci: Asliddin Rustamow, Diloram Taszmuchamedowa i Akmal Saidow. Natomiast w wyborach prezydenckich, które odbyły się w dniu 29 marca 2015 r. Isłam Karimow otrzymał 90,39\% głosów. Drugie miejsce zajął kandydat Partii Demokratycznej Akmal Saidow, który zdobył 3,08\% głosów, kandydat Partii LudowoDemokratycznej Hotamżon Ketmonow uzyskał 2,92\% głosów i na ostatnim miejscu z wynikiem 2,05\% uplasował się kandydat Partii Socjal-Demokratycznej „Adolat” Narimon Umarow. Frekwencja wyborcza wyniosła 91,08\% uprawnionych do głosowania. W wyborach w 1994 i 2000 roku kandydaturę Karimowa zgłosiła ,partia władzy" - Ludowo-Demokratyczna Partia Uzbekistanu, zaś w wyborach w 2007 roku - Liberalno-Demokratyczna Partia Uzbekistanu, która tak jak wszystkie pozostałe partie, mające reprezentację w Olij Madżlisie tworzy koncesjonowaną opozycję. We wszystkich wyborach prezydenckich w Uzbekistanie zachodni obserwatorzy, w tym OBWE wskazali na liczne naruszenia i nieprawidłowości, w związku z czym nie zostały one uznane za wolne i demokratyczne ${ }^{12}$.

Konstytucja Uzbekistanu przyznaje Prezydentowi rozległe kompetencje, które można podzielić na kilka zasadniczych obszarów: w stosunku do parlamentu, w stosunku do rządu, w dziedzinie polityki zagranicznej, w zakresie obronności i bezpieczeństwa państwa, uprawnienia wobec innych organów państwowych oraz tradycyjne uprawnienia głowy państwa w stosunkach wewnętrznych.

11 T. Bodio, T. Mołdawa, Konstytucje państw..., op. cit., s. 489 i 503.

12 Sz. Achmadżonow, Jest' li szans pobiedit' I. Karimowa na wyborach w Uzbiekistanie?, http://www. centrasia. ru/newsA.php?st=1191488340 (data dostępu: 16.06.2015 r.); Ambasada Rzeczypospolitej Polskiej w Taszkencie, Wybory prezydenckie w Republice Uzbekistanu, http://www.taszkent.msz.gov.pl/pl/c/MOBILE/aktualnosci/0 0015_04_01_wybory_prezydenta_ru (data dostępu: 04.07.2015 r.). 
W zakresie stosunków z parlamentem Prezydent Uzbekistanu posiada bardzo szerokie uprawnienia, które obejmują: prawo inicjatywy ustawodawczej, podpisywanie ustaw i zarząadzanie ich ogłoszenia, prawo weta zawieszającego, zwoływania posiedzeń nadzwyczajnych obydwu izb Olij Madżlisu, prawo do zwracania się z orędziem do Olij Madżlisu oraz prawo rozwiązania parlamentu. Prezydent ma również istotny wpływ na skład Senatu.

Prezydent Uzbekistanu posiada duże możliwości uczestnictwa w procesie ustawodawczym, ponieważ może on brać udział w posiedzeniach Izby Ustawodawczej i Senatu Olij Madżlisu, a także ich organów - kengaszy, komitetów i komisji, a to w praktyce oznacza, że może on uczestniczyć nie tylko w inicjowaniu projektów ustaw, ale i w procesie ich tworzenia. Podczas rozpatrywania projektów ustaw Prezydent ma bowiem możliwość zabrania głosu i zgłoszenia swoich uwag (art. 81 i 83). Do tego Prezydent może zwoływać posiedzenia nadzwyczajne Izby Ustawodawczej i Senatu Olij Madżlisu, a jego projekty ustawodawcze są rozpatrywane w pierwszej kolejności ${ }^{13}$.

Konstytucja nadaje Prezydentowi uprawnienia związane $\mathrm{z}$ podpisywaniem i ogłaszaniem ustaw (art. 93 ust. 17). Zgodnie z art. 84 ustawa przyjęta przez obydwie izby Oliy Majlis jest przedkładana Prezydentowi do podpisu w terminie 10 dni. Prezydent może w ciągu 30 dni od otrzymania tekstu ustawy podpisać ją i zarządzić jej ogłoszenie lub odesłać ustawę ze swoimi uwagami do Olij Madżlisu w celu jej powtórnego rozpatrzenia, realizując w ten sposób prawo do zastosowania weta zawieszającego. Po ponownym uchwaleniu ustawy przez Izbę Ustawodawczą i Senat Olij Madżlisu, Prezydent ma 14 dni na jej podpisanie.

Prezydent Uzbekistanu ma znaczący wpływ na skład Senatu, ponieważ wybiera on 16 jego członków spośród obywateli cieszących się wyjątkowym autorytetem, posiadających duże doświadczenie zawodowe lub zasłużonych w dziedzinie nauki, literatury i sztuki oraz innych sferach działalności państwowej i społecznej (art. 77). W tym wypadku - poza wskazaniami Konstytucji - w praktyce liczy się przede wszystkim orientacja polityczna kandydatów i ich lojalność wobec obozu prezydenckiego. Ponadto na wniosek Prezydenta spośród grona senatorów wybierany jest Przewodniczący Senatu i jego zastępcy ${ }^{14}$.

Prezydent może na podstawie art. 93 ust. 7 i art. 81 Konstytucji zwracać się do Izby Ustawodawczej i Senatu Olij Madżlisu z dorocznym orędziem, dotyczącym najważniejszych problemów życia społeczno-gospodarczego oraz wewnętrznej i zagranicznej polityki państwa. Aczkolwiek orędzie nie jest właściwą inicjatywą ustawodawczą, to jednak pozwala ono na przedstawienie konkretnych intencji

\footnotetext{
13 Vide: Zakon Riespubliki Uzbiekistan nr 522-II ot 29 sientjabrja 2003 goda O Riegłamientie Zakonodatiel'noj pałaty Olij Madżlisa Riespubliki Uzbiekistan (po sostojaniju na 14 maja 2014 goda), http://www.parliam ent.gov.uz/ru/regulations.php (data dostępu: 19.06.2015 r.), art. 3; Zakon Riespubliki Uzbiekistan nr 523-II ot 29 sientjabrja 2003 goda O Riegłamientie Sienata Olij Madżlisa Riespubliki Uzbiekistan(po sostojaniju na 16 aprielja 2014 goda), http://www.senat.uz/ru/documents/index.html (data dostępu: 19.06.2015 r.), art. 3.

Zakon Riespubliki Uzbiekistan nr 523-II..., op. cit., art. 4.
} 
i oczekiwań ze strony ośrodka prezydenckiego, a także może stanowić zapowiedź przyszłych projektów ustawodawczych.

Bardzo ważnym instrumentem oddziaływania Prezydenta na Olij Madżlis jest prawo do przedterminowego skrócenia kadencji obydwu izb parlamentu. Prezydent korzysta z tego prawa po uzgodnieniu swojego stanowiska z Sądem Konstytucyjnym RU w przypadkach pojawienia się w Izbie Ustawodawczej bądź Senacie nieprzezwyciężalnych rozbieżności, zagrażających ich normalnemu funkcjonowaniu, wielokrotnego wydawania decyzji sprzecznych z Konstytucją lub powstaniem nieprzezwyciężalnych rozbieżności pomiędzy Izbą Ustawodawczą a Senatem, które zagrażają normalnemu funkcjonowaniu Olij Madżlisu (art. 95). Formuła „nieprzezwyciężalnych trudności” daje w istocie Prezydentowi Uzbekistanu pole do szerokiej interpretacji i dużej swobody przy podejmowaniu decyzji, dotyczącej przedterminowego skrócenia kadencji parlamentu. Prezydent może również rozwiązać parlament w przypadku, kiedy ten dwukrotnie nie udzieli wotum zaufania desygnowanym przez niego kandydatom na stanowisko premiera (art. 98).

W stosunku do Gabinetu Ministrów Konstytucja nadała Prezydentowi następujące uprawnienia: formowanie składu rządu i dokonywanie w nim zmian personalnych, przewodniczenie posiedzeniom Gabinetu Ministrów, podejmowanie decyzji w sprawach należących do kompetencji Gabinetu Ministrów, w tym anulowanie jego uchwał i rozporządzeń oraz rozporządzeń premiera, jak również tworzenie i likwidacja za zgodą Olij Madżlisu ministerstw, komitetów państwowych i innych agend rządowych (art. 93 ust. 8, 10-11,16). Prezydent ma również duży wpływ na obsadę personalną aparatu wykonawczego rządu w terenie, bowiem na wniosek premiera może on mianować i zwalniać hokimów obwodowych (odpowiednik wojewody) i miasta Taszkent, natomiast samodzielnie może on zwalniać z zajmowanych stanowisk hokimów miejskich i rejonowych w przypadku naruszenia przez nich Konstytucji, ustawodawstwa lub popełnienia czynów uwłaczających honorowi i godności hokima. Decyzje te jednak wymagają zatwierdzenia ze strony odpowiednich rad deputowanych ludowych (art. 93 ust. 15).

Uprawnienia Prezydenta w stosunku do innych organów państwowych niż Olij Madżlis i Gabinet Ministrów mają głównie kreacyjny oraz gwarancyjny i koordynujący charakter ich działalności. Kreacyjne kompetencje Prezydenta obejmują mianowanie i odwoływanie Prokuratora Generalnego RU oraz przewodniczącego Izby Obrachunkowej, co wymaga jednak zatwierdzenia przez Senat. Prezydent zgłasza i przedstawia Senatowi kandydatury na stanowiska przewodniczących i sędziów Sądu Konstytucyjnego, Sądu Najwyższego, Naczelnego Sądu Gospodarczego, prezesa Banku Centralnego RU, przewodniczącego Komitetu Państwowego ds. Ochrony Przyrody oraz powołuje i odwołuje sędziów sądów obwodowych, międzyrejonowych, rejonowych, miejskich, gospodarczych i wojskowych (art. 93 ust. 13-14). 
Kompetencje Prezydenta w dziedzinie polityki zagranicznej obejmują: reprezentowanie państwa $\mathrm{w}$ stosunkach międzynarodowych, negocjowanie i zawieranie umów międzynarodowych, a przy tym gwarantowanie przyjętych w ten sposób zobowiązań, mianowanie przedstawicieli dyplomatycznych i konsularnych za granicą oraz przyjmowanie listów uwierzytelniających od przedstawicieli dyplomatycznych państw trzecich (art. 93 ust. 3-5).

Prezydent posiada rozległe kompetencje w zakresie obronności i bezpieczeństwa państwa. Zgodnie z art. 93 ust. 20 jest on najwyższym zwierzchnikiem Sił Zbrojnych Uzbekistanu, mianuje i dymisjonuje naczelne dowództwo Sił Zbrojnych oraz nadaje stopnie $\mathrm{w}$ korpusie oficerskim. W przypadkach szczególnych, związanych z realnym zagrożeniem zewnętrznym, masowym naruszaniem porządku społecznego, wielkimi katastrofami, klęskami żywiołowymi i epidemiami, Prezydent może wprowadzić stan wyjątkowy w państwie lub w jego części, który następnie musi być zatwierdzony przez parlament $\mathrm{w}$ terminie trzech dni. Natomiast $\mathrm{w}$ przypadku napaści na Uzbekistan lub konieczności wypełnienia zobowiązań sojuszniczych Prezydent ogłasza stan wojny, co wymaga zatwierdzenia przez parlament w terminie również trzech dni (art. 93 ust. 18-19). Ze sferą bezpieczeństwa państwowego związane jest jeszcze jedno uprawnienie Prezydenta, a mianowicie prawo do organizowania przez niego Służby Bezpieczeństwa Narodowego Republiki Uzbekistanu, w tym do mianowania i dymisjonowania szefa tych służb. To ostanie wymaga jednak zatwierdzenia przez Senat Olij Madżlisu (art. 93 ust. 24).

W zakresie tradycyjnych uprawnień głowy państwa Konstytucja nadała Prezydentowi RU prawo do: decydowania w sprawach obywatelstwa Uzbekistanu, udzielania azylu politycznego, przyznawania orderów, medali i dyplomów państwowych, nadawania tytułów kwalifikowanych i honorowych Uzbekistanu oraz stosowania prawa łaski we wszystkich sprawach wobec osób skazanych przez uzbeckie sądy. Prezydent może także wnosić do Senatu Olij Madżlisu swoje uwagi dotyczące przyjęcia aktów o amnestii (art. 93 ust. 21-23).

W zakresie swoich kompetencji Prezydent wydaje dekrety i rozporządzenia (art. 94 Konstytucji). Niektóre z nich wymagają zatwierdzenia przez Olij Madżlis, jak dekret dotyczący wprowadzenia stanu wojny lub dekret wprowadzający stan wyjątkowy na terytorium państwa lub jego części (art. 93 ust. 18-19 Konstytucji) ${ }^{15}$.

5. Nowelizacja Konstytucji z dnia 11 kwietnia 2007 r. wprowadziła istotną zmianę w przepisie art. 89, odnoszącego się do funkcji i zadań Prezydenta RU. Na jej podstawie Prezydent Uzbekistanu przestał być szefem władzy wykonawczej, a zamiast tego umieszczono formułę, że „zapewnia on harmonijne funkcjonowanie i współdziałanie organów władzy państwowej”. Przepis ten formalnie sprzyjał tworzeniu mechanizmów równowagi w trójpodziale władzy, bowiem Prezy- 
dent przestał być „szefem władzy wykonawczej”, co wzmocniło pozycję premiera. Inne przyjęte wówczas zmiany zwiększyły swobodę Prezydenta w prawie nominacji i odwoływania hokimów obwodowych oraz hokimów miasta Taszkent, ponieważ decyzje te nie wymagały już zatwierdzenia ze strony odpowiednich rad deputowanych ludowych. Regulacje te w istocie zapewniały centralizację władzy w rękach Prezydenta Uzbekistanu (art. 89 ust. 15 i art. 102 Konstytucji) $^{16}$.

Kolejną zmianą normatywną w Uzbekistanie, która była niewątpliwie wyłomem w dotychczasowych regulacjach spełniających zasadniczo standardy stawiane państwom demokratycznym, było przyjęcie przez Olij Madżlis w dniu 25 grudnia 2008 r. ustawy o wniesieniu zmian i uzupełnień do niektórych aktów ustawodawczych Republiki Uzbekistanu w związku z doskonaleniem ustawodawstwa o wyborach. Ustawa ta pozbawiła grupy inicjatywne obywateli prawa do zgłaszania swoich kandydatów w wyborach prezydenckich i parlamentarnych. Jedynymi podmiotami uprawnionymi do zgłaszania kandydatów na urząd Prezydenta Uzbekistanu i deputowanych Olij Madżlisu stały się odtąd partie polityczne ${ }^{17}$.

Nowelizacja Konstytucji RU przyjęta w dniu 18 września 2011 r. na podstawie ustawy o wniesieniu zmian i uzupełnień do poszczególnych artykułów Konstytucji Republiki Uzbekistanu utrzymała dotychczasowe regulacje dotyczące swoistej „nieodpowiedzialności” Prezydenta Uzbekistanu. W przepisie art. 96 przewidziano bowiem jedynie sytuację ,niemożności sprawowania urzędu przez urzędującego Prezydenta Republiki Uzbekistanu". W takim przypadku jego obowiązki tymczasowo przejmuje Przewodniczący Senatu Olij Madżlisu, zaś w terminie trzech miesięcy powinny być przeprowadzone nowe wybory Prezydenta Uzbekistanu. Pozostałe zmiany dotyczyły korekt w uprawnieniach Prezydenta. Przede wszystkim przekazywały mu możliwość przewodniczenia na posiedzeniach Gabinetu Ministrów Republiki Uzbekistanu, co znacząco wzmacniało jego pozycję ustrojową w relacji z egzekutywą (art. 93 ust. 16) ${ }^{18}$.

6. Niezależnie od regulacji normatywnych (przede wszystkim konstytucyjnych i ustawowych) o rzeczywistej pozycji ustrojowej każdego prezydenta decydują jeszcze indywidualne cechy jego osobowości i posiadane predyspozycje. Wskazuje się w tym względzie głównie na tzw. charyzmę, otwartość, łatwość komunikowania się i umiejętności koncyliacyjne, które przekładają się nie tylko na poziom poparcia

16 Zakon Riespubliki Uzbiekistan nr 3RU-89 ot 11 aprielja 2007 goda O wniesieniji poprawok w stat'i Konstituciji Riespubliki Uzbiekistan (stat'i 89, punkt 15 ctat'i 93, czast' wtoraja stat'i 102), http://lex.uz/Pages/G etAct.aspx?lact_ id=1164976\&ONDATE=01.01.2008 00\#1165000 (data dostępu: 20.06.2015 r.).

17 Zakon Riespubliki Uzbiekistan nr 3RU-194 ot 25 diekabrja 2008 goda O wniesieniji izmienienij i dopołnienij w niekotoryje zakonodatiel'nyje akty Riespubliki Uzbiekistan w swiazi s sowierszienstwowanijem zakonodatiel'stwa o wyborach, http://www.lex.uz/pages/GetAct.aspx?lact_id=1421433\&ONDATE=01.07.2009\% 2000\# 1421481 (data dostępu: 21.06.2015 r.).

18 Zakon Riespubliki Uzbiekistan nr 3RU-194 ot 18 aprielja 2011 goda O wniesieniji izmienienij i dopołnienij w otdiel'nyje stat'i Konstituciji Riespubliki Uzbiekistan (stat'i 78, 80, 93, 96 i 98), http://www.lex.uz/ pages/GetAct. aspx?lact_id=1773893\&ONDATE=19.04.2011\%00\#174322 (data dostępu: 21.06.2015 r.). 
społecznego, lecz również na relacje prezydenta z parlamentem i rządem. Cechy te są pożądane nie tylko w państwie demokratycznym, zwłaszcza o parlamentarnym systemie rządów, lecz mają również istotne znaczenie w systemie autorytarnym, bowiem mogą mobilizować rządzonych do akceptacji poczynań władzy bez uciekania się tej ostatniej do rozwiązań siłowych ${ }^{19}$. W realiach Uzbekistanu i w ogóle państw regionu Azji Centralnej - zgodnie z tradycjami i aksjologią kultury trybalnej - liczy się jeszcze pochodzenie głowy państwa i jego usytuowanie w układzie etnoregionalnym i klanowym.

Trybalizm czy według części badaczy kultura polityczna więzi i wynikające z nich implikacje w życiu politycznym i społecznym są zjawiskiem bardzo charakterystycznym dla całego regionu Azji Centralnej. Nie można zrozumieć kanonów polityki uprawianej w państwach Azji Centralnej oraz wydarzeń tam zachodzących z pominięciem podziałów społecznych, w których najważniejszą rolę odgrywają nie klasy czy warstwy w rozumieniu europejskim, lecz wspólnoty rodowo-plemienne i klanowo-terytorialne. Wyróżnione wspólnoty łączy genealogia, solidarność subetniczna i regionalno-plemienna oraz patronacka zależność członków od elit klanowych. Wybrana „demokratycznie” elita rządząca jest zróżnicowana według przynależności klanowej. Jej miejsce w hierarchii władzy decyduje o sferze i zakresie wpływów konkretnych klanów w kraju i regionie. Wpływ na awans do elit władz centralnych, regionalnych i lokalnych mają takie czynniki, jak przynależność do rodu, plemienia i klanu, zajmowana pozycja w strukturach tych wspólnot, lojalność i posłuszeństwo wobec przywódców, zaś w dalszej kolejności kompetencje czy wykształcenie. Powszechnymi zjawiskami związanymi z trybalizmem są klientelizm, korupcja i nepotyzm ${ }^{20}$.

Iłam Karimow wywodzi się z klanu samarkandzkiego. Należy podkreślić, że jego wybór na stanowisko I sekretarza KC Komunistycznej Partii Uzbekistanu w dniu 23 czerwca 1989 r. po dymisji Rafika Nišanova poprzedzony był etapem negocjacji najbardziej wpływowych przedstawicieli grup regionalnych $\mathrm{w}$ elitach ówczesnej władzy na szczeblu republikańskim i centralnym. Brali w nich udział ze strony grupy samarkandzkiej Ismail Džurabekov i Abdulaziz Kamilov, taszkent-

Vide: E. Zieliński, Prezydent Federalny, (w:) S. Sulowski, K. A. Wojtaszczyk (red.), System polityczny Republiki Federalnej Niemiec, Warszawa 2005, s. 103; A. Turska-Kawa, Przywództwo polityczne jako wynik wzajemnej relacji między przywódcą a jego zwolennikami, (w:) M. Hartliński (red.), Przywództwo polityczne w Polsce i na świecie, Olsztyn 2013, s. 55-71; P. Żukiewicz, Instytucja prezydenta czy przywództwo prezydenckie - próba rozstrzygnięcia dylematu, (w:) Ibidem, s. 86-87; J. Wiatr, Przywództwo polityczne: studium politologiczne, Łódź 2008, s. 67-90; E. Marciniak, Kompetencje przywódcy politycznego, (w:) T. Bodio (red.),Przywództwo polityczne, Warszawa 2001, s. 98-109; P. Żukiewicz, Przywództwo polityczne: teoria i praktyka, Warszawa 2011, s. 182-183. T. Bodio, Układy klanowe jako mechanizm polityki (na przykładzie państw Azji Centralnej), (w:) T. Bodio, W. Jakubowski, A. Wierzbicki (red.), Transformacja społeczeństwa i władzy w postradzieckiej Azji Centralnej: studia i rozprawy, Pułtusk 2008, s. 152-162; N.K. Aalijewa, Politiczieskije prociessy w Kyrgyzstanie i drugich stranach Cientralnoj Aziji - mieżdu tradicijej i modiernizacijej, (w:) A.K. Dżusupbekov, W. Jakubowski, P. Załęski (red.), Kirgistan: problemy kulturowe i społeczno-polityczne. Kyrgyzstan: kul'turnyje i social'no-politiczieskije probliemy, Biszkek - Warszawa 2011, s. 335-347; P. Załęski, Kultura polityczna więzi w Azji Centralnej, Warszawa 2011, s. 45-48; idem, Regionalizm, klientelizm i klanowość jako podstawy kultury politycznej w Uzbekistanie, (w:) Transformacja społeczeństwa..., op. cit., s. 281-285. 
czyk Šukurulla Mirsaidov oraz przedstawiciel grupy fergańskiej - Rustam Achmedov. Karimow spełniał podstawowe kryteria postawione przez negocjujących, tzn. miał wyłącznie lokalną wówczas legitymizację, nie był prorosyjski i gwarantował zachowanie, a nawet wzrost znaczenia powiązań nieformalnych. Po nominacji Karimow oparł politykę kadrową o własną grupę samarkandzką, jak również taszkencką i w pewnej części fergańską, chociaż bez kadr z Namanganu i Andiżanu. Po pierwszych powszechnych wyborach prezydenckich Isłam Karimow nominował swojego konkurenta Šukurullę Mirsaidova na stanowisko Wiceprezydenta Uzbekistanu i realizował politykę balansu między grupą samarkandzką a taszkencką, współkontrolując także tę ostatnią. W pierwszych latach urzędowania Karimowa rolę szarej eminencji spełniał Ismail Džurabekov, wychowany w tej samej mahalli (wspólnota sąsiedzka licząca 500-1000 gospodarstw domowych) Samarkandy co Prezydent Uzbekistanu. Chociaż oficjalnie Isłam Karimow potępia trybalizm i układy klanowe, to jednak jest on ,zmuszony” do prowadzenia polityki balansu między czołowymi grupami Uzbekistanu, czego widocznym dowodem są dymisje i nominacje, zwłaszcza te z 2002 i 2003 r. W ich wyniku Samarkandzczyk Suprjat Mirzojew objął stanowisko premiera, zaś wicepremierem rządu został Taszkentczyk Alisher Azizhojev. Najbliżsi współpracownicy Prezydenta, ministrowie i ich aparat są dobierani zawsze wedle przynależności klanowej²1.

7. System rządów w Uzbekistanie od czasu wejścia w życie Konstytucji z 1992 r. jest zbliżony do systemu rządów prezydenckich (chociaż pod względem formalnym nie brakuje mu również cech systemu semiprezydenckiego), ze wskazaniem jednak na bardzo silną pozycję głowy państwa, co może go kwalifikować nawet do systemu superprezydenckiego ${ }^{22}$. W konstrukcjach ustrojowych państw Azji Centralnej i w ogóle obszaru WNP jest wiele kompilacji i mutacji oraz są widoczne przemieszania rozwiązań właściwych zarówno dla parlamentarnego systemu rządów, jak i prezydenckiego systemu rządów. Wzorem były głównie rozwiązania stosowane w państwach Europy Zachodniej i Stanach Zjednoczonych, kompilowane w różnych i nie do końca przemyślanych proporcjach. Dlatego też w przypadku państw tego regionu z uwagi na skalę odrębności wiele pojęć właściwych dla klasycznych modeli systemu rządów może budzić zastrzeżenia i wątpliwości, a nawet nie znajdować odniesienia ${ }^{23}$.

21 T. Bodio, P. Załęski, Elity władzy w Azji Centralnej: tradycja - modernizacja - etnopolityka, Warszawa 2008, s. 153-154; P. Załęski, Regionalizm..., op. cit., s. 285-302.

22 Jednoznaczne określenie systemów politycznych państw powstałych na obszarze byłego Związku Radzieckiego po jego rozpadzie może niekiedy sprawiać spore trudności z uwagi na niemałe odstępstwa od systemów modelowych, na co uwagę zwracają w polskiej literaturze naukowej m.in. prof. Andrzej Antoszewski i prof. Bożena Dziemidok-Olszewska. Vide: A. Antoszewski, R. Herbut, Systemy polityczne współczesnej Europy, Warszawa 2007, s. 189-192; B. Dziemidok-Olszewska, Instytucja prezydenta w państwach Europy Środkowej i Wschodniej, Lublin 2003, s. 126-129.

23 J. Szymanek, Systemy rządów w krajach WNP: metodologia badań ustrojowo-porównawczych, (w:) T. Bodio (red.), Przywództwo, elity i transformacje w krajach WNP, Warszawa 2010, s. 247-250, 262-275. 
System rządów w niepodległym Uzbekistanie wyrósł z jednej strony na bazie autorytarnej tradycji oraz kultury wodzowskiej i trybalnej społeczeństwa Uzbekistanu i w ogóle całego regionu Azji Centralnej, a z drugiej strony - z potrzeby silnego ośrodka kierowniczego, niezbędnego do dokonania kontrolowanych przemian ustrojowych oraz skutecznego przeciwstawienia się ekstremizmowi i fundamentalizmowi islamskiemu. Ważnym elementem uzbeckiej transformacji ustrojowej stała się personifikacja polityki i ciągłość władzy. Sam urzędujący nieprzerwanie od marca 1990 r. Prezydent Isłam Karimow stwierdził, że „...w naszym kraju może być albo demokracja, albo porządek. Ja wybieram to drugie". Szukając ideologicznej podbudowy swoich działań Isłam Karimow skoncentrował się na jedności i jednomyślności, która jest ,największym obywatelskim obowiązkiem”. ${ }^{24}$ Po wyborach prezydenckich w grudniu 1991 r. Karimow nie ukrywał już swoich intencji do centralizacji władzy. W latach 1992-1993 rozbił on prawie całkowicie opozycję polityczną i osłabił ruchy religijne, uzyskując w ten sposób niezagrożoną pozycję w Uzbekistanie. Czołowi przedstawiciele opozycji demokratycznej, przede wszystkim z partii „Erk” i „Birlik” bądź wyjechali za granicę, bądź odbywają długoletnie wyroki pozbawienia wolności w uzbeckich zakładach karnych. Liczba więźniów politycznych jest oceniana na 7-10 tys. Natomiast najbardziej radykalna i ekstremistyczna część opozycji, jak Islamski Ruch Uzbekistanu (IRU) zdecydowała się na walkę zbrojną i zamachy terrorystyczne. Przeciwko władzom Uzbekistanu IRU ogłosiła nawet świętą wojnę - dżihad. W Olij Madżlisie zasiadają poza przedstawicielami partii proprezydenckich wyłącznie przedstawiciele tzw. konstruktywnej opozycji, co w istocie oznacza opozycję koncesjonowaną i w pełni kontrolowaną ${ }^{25}$.

Wszelkie przejawy buntu przeciwko władzy są natychmiast thumione przez siły bezpieczeństwa. Do najbardziej krwawych wydarzeń doszło w maju 2005 r. w Andiżanie, gdzie pokojowe protesty społeczne przeciwko polityce Prezydenta zostały stłumione przy użyciu wojska pod pozorem walki z ekstremizmem islamskim. Zginęły i odniosły wówczas rany setki demonstrantów, chociaż według oficjalnej wersji rządowej tylko 169 - głównie „bandytów”. Wielu ludzi w obawie przed represjami uciekło też do Kirgistanu ${ }^{26}$. Prezydent stał się nie tylko niekwestionowanym przywódcą w państwie, ale również kreuje się na lidera całej poradzieckiej Azji Centralnej, czego uzasadnieniem ma być potencjał demograficzny, gospodarczy oraz historia Uzbekistanu. Nad prawidłowym wizerunkiem przywódcy czuwa zresztą

I. Karimow, Uzbekistan na progu XXI wieku, Warszawa 2001, s. 113-117; L. Roszyk, Transformacja uzbecka: przełom czy kontynuacja, (w:) Uzbekistan..., op. cit., s. 175-176.

G.R. Capisani, Nowe państwa Azji Środkowej, Warszawa 2004, s. 130-134; S. Zapaśnik, „Walczący islam” w Azji Centralnej, Wrocław 2006, s. 99-112; A. Bielewicz, Isłam Karimow: najbardziej krwawy z satrapów, http://www. psz.pl/117-polityka/islam-karimow-najbardziej-krwawy-sposrod-satrapow (data dostępu: 28.10 .2015 r.).

A. Zamarajewa, Masakra w Andiżanie - między biedą, dyktaturą a rywalizacją klanową, (w:) Transformacja społeczeństwa..., op. cit., s. 105-119. 
Państwowy Komitet ds. Prasy, który w rzeczywistości sprawuje funkcje cenzorskie, chociaż Konstytucja gwarantuje wolność środków masowego przekazu (art. 67)27.

Konstytucja z 1992 roku mimo formalnego podziału władzy wyraźnie ustanawia - jak wyżej już wskazano - dominację władzy wykonawczej w systemie organów państwowych Uzbekistanu. Powołanie Gabinetu Ministrów należy do Prezydenta, chociaż jego decyzja o desygnacji szefa rządu musi uzyskać zgodę Olij Madżlisu. Dwukrotne odrzucenie prezydenckiej kandydatury na stanowisko premiera daje głowie państwa możliwość przedterminowego skrócenia kadencji parlamentu. Prezydent poprzez prawo przewodniczenia posiedzeniom Gabinetu Ministrów w rzeczywistości ma decydujący wpływ na jego decyzje. Konstytucja powierza Prezydentowi szerokie uprawnienia kreacyjne w stosunku do organów władzy wykonawczej i administracji oraz rolę kierowania ich pracą i zapewnienia harmonijnego współdziałania.

Prezydent Uzbekistanu posiada także szersze uprawnienia wobec parlamentu, niż występujące w typowych współczesnych systemach prezydenckich. Posiada on bowiem prawo inicjatywy ustawodawczej, możliwość zwoływania sesji nadzwyczajnych izb Olij Madżlisu i uczestnictwa w ich pracach, prawo weta ustawodawczego, promulgacji ustaw i wreszcie rozwiązania parlamentu. Należy jeszcze podkreślić, że skład parlamentu, na który Prezydent ma istotny wpływ poprzez istniejący system partyjny oraz możliwości kreacyjne w stosunku do Senatu, daje mu gwarancje lojalności politycznej i prawie nieograniczone możliwości wpływania na proces ustawodawczy. Sam Prezydent z kolei nie odpowiada politycznie i konstytucyjnie, a jego ,zabezpieczeniem” po zakończeniu kadencji jest przewidziane przez Konstytucję stanowisko dożywotniego członka Senatu Olij Madżlisu² ${ }^{28}$. Dlatego też niezależnie od regulacji normatywnych, które i tak należy postrzegać jedynie za pozornie spełniające standardy demokratyczne i gwarantujące pluralizm polityczny, funkcjonujący realnie w Uzbekistanie system rządów należy zakwalifikować jako autorytarny i to ze wskazaniem, że jest to tzw. twardy autorytaryzm.

Podsumowując powyższe rozważania dotyczące ewolucji pozycji ustrojowej Prezydenta Uzbekistanu w latach 1990-2015 można stwierdzić, że proces zmian w tym przedmiocie był raczej typowy dla regionu państw Azji Centralnej, tzn. odbywał się pod kontrolą ośrodka prezydenckiego i służył zapewnieniu głowie państwa jak najsilniejszej pozycji ustrojowej w stosunku do pozostałych naczelnych organów państwa. W ewolucji pozycji ustrojowej Prezydenta zaznaczyły się wyraźnie trzy etapy. Pierwszy etap otworzyło ustanowienie instytucji Prezydenta RU w marcu 1990 r., zaś zakończyło wejście w życie Konstytucji z dnia 8 grudnia 1992 r. Prezydent początkowo uzyskał niewielki zakres uprawnień i do tego nie były one precyzyjnie rozdzielone w odniesieniu do Prezydium Rady Najwyższej, która nadal

27 J. Adamowski, Środki masowego przekazu, (w:) Uzbekistan..., op. cit., s. 161-164.

28 J. Szukalski, System konstytucyjny Uzbekistanu, Warszawa 2014, s. 86. 
pełniła funkcje głowy państwa. Dopiero nowelizacja Konstytucji Uzbeckiej SRR z dnia 8 listopada 1990 r. nadała Prezydentowi znacznie szersze uprawnienia, bowiem stał się on szefem władzy wykonawczej. Drugi etap zapoczątkowała nowa Konstytucja, która przyznała Prezydentowi funkcje głowy państwa i szefa władzy wykonawczej. Do tego Prezydent otrzymał szeroki zakres kompetencji, a nikłe możliwości jego odwołania sprawiły, że stał się on praktycznie nie tylko politycznie, ale i konstytucyjnie nieodpowiedzialny.

Nowelizacja ustawy zasadniczej z dnia 7 kwietnia 2007 r. uchylając funkcję szefa władzy wykonawczej w jej miejsce wprowadziła formułę, że Prezydent zapewnia harmonijne funkcjonowanie i współdziałanie organów władzy państwowej. Aczkolwiek była to zmiana istotna i formalnie należy ją uznać za początek trzeciego etapu, to nie wpłynęła ona już znacząco na zachowanie przez Prezydenta Uzbekistanu silnej pozycji ustrojowej, która została właściwie ugruntowana od wejścia w życie Konstytucji z 1992 r. Autorytarny styl sprawowania władzy przez Isłama Karimowa, spacyfikowanie opozycji i prowadzona przez niego polityka umiejętnego balansu między grupami klanowymi w państwie stwarza dodatkowe mocne przesłanki utrzymania silnej pozycji ustrojowej przez Prezydenta Uzbekistanu.

\section{BIBLIOGRAFIA}

Konstitucija (Osnownoj Zakon) Uzbekskoj Sowietskoj Socjalisticzieskoj Riespubliki (prinjata na wnieoczieriednoj sziestoj siessiji Wierchownogo Sowieta Uzbekskoj SRR diewjatogo sozywa 19 aprielja 1978 goda). Dodano Czerwiec 12, 2015. http://zakonu z.uzshar.com/?document=5990.

Konstytucja Rzeczypospolitej Polskiej z dnia 2 kwietnia 1997 r. 2015. Dz.U. Nr 78, poz. 83 z późniejszymi zmianami (zm.: Dz.U. 2001, Nr 28, poz. 319; 2006, Nr 200, poz. 1471; 2009, Nr 114, poz. 346). W Teksty ustaw Becka. Prawo konstytucyjne, 25. Wydawnictwo C.H. Beck w Warszawie.

Zakon Uzbiekskoj SSR nr 4-XII ot 24 marta 1990 goda. Ob uczrieżdieniji posta Priezidienta Riespubliki Uzbiekistan i wniesieniji izmienienij i dopołnienij w Konstituciju (Osnownoj zakon) Riespubliki Uzbiekistan. Dodano Czerwiec 11, 2015. http://www.parliament.gov.uz/ru/ law/1990/2800/.

Zakon Uzbiekskoj Sowietskoj Socialisticzieskoj Riespubliki nr 156-XII ot 1 nojabrja 1990 goda. O sowierszienstwowaniji struktury ispołnitiel'noj i rasporjaditiel'noj własti w Uzbiekskoj SSR i wniesieniji izmienienij i dopołnienij w Konstituciju (Osnownoj Zakon) Uzbiekskoj SSR. Dodano Czerwiec 12, 2015. http://www.lex.uz/Pages/GetAct.aspx?lact_id=957016.

Zakon Riespubliki Uzbiekistan $\mathrm{nr} \quad 3 \mathrm{RU}-89$ ot 11 aprielja 2007 goda. O wniesieniji poprawok w stat'i Konstituciji Riespubliki Uzbiekistan (stat'i 89, punkt 15 ctat'i 93, czast' wtoraja stat'i 102). Dodano Czerwiec 20, 2015. http://lex.uz/Pages/GetAct.aspx ?lact_id=1164976\&ONDATE=01.01.200800\#1165000.

Zakon Riespubliki Uzbiekistan $\mathrm{nr}$ 3RU-194 ot 18 aprielja 2011 goda. O wniesieniji izmienienij i dopołnienij w otdiel'nyje stat'i Konstituciji Riespubliki Uzbiekistan (stat'i 78, 80, 93, 96 i 98). Dodano Czerwiec 21, 2015. http://www.lex.uz/pages/GetAc t.aspx?lac t_id=1773893\&ONDATE=19.04.2011\%00\#174322. 
Zakon Riespubliki Uzbiekistan nr 3 RU-305 ot 12 diekabrja 2011 goda. O wniesieniji poprawki w stat'ju 90 Konstituciji Riespubliki Uzbiekistan. Dodano Czerwiec 17, 2015. http://www.lex. uz/pages/GetAct.aspx?lact_id=2216248\&ONDATE=28.12.2011\%2000\#2216403.

Zakon Riespubliki Uzbiekistan nr 522-II ot 29 sientjabrja 2003 goda. O Riegłamientie Zakonodatiel'noj pałaty Olij Madżlisa Riespubliki Uzbiekistan (po sostojaniju na 14 maja 2014 goda). Dodano Czerwiec 19, 2015. http://www.parliament.gov.uz/ru/regula tions.php.

Zakon Riespubliki Uzbiekistan nr 523-II ot 29 sientjabrja 2003 goda. O Riegłamientie Sienata Olij Madżlisa Riespubliki Uzbiekistan(po sostojaniju na 16 aprielja 2014 goda). Dodano Czerwiec 19, 2015. http://www.senat.uz/ru/documents/index.html.

Zakon Riespubliki Uzbiekistan nr 3RU-194 ot 25 diekabrja 2008 goda. O wniesieniji izmienienij i dopołnienij w niekotoryje zakonodatiel'nyje akty Riespubliki Uzbiekistan w swiazi s sowierszienstwowanijem zakonodatiel'stwa o wyborach. Dodano Czerwiec 21, 2015. http://www.lex. uz/pages/GetAct.aspx?lact_id=1421433\&ONDAT E=01.07.2009\% 2000\#1421481.

Aalijewa Nurzat K. Politiczieskije prociessy w Kyrgyzstanie i drugich stranach Cientralnoj Aziji mieżdu tradicijej i modiernizacijej. W Kirgistan: problemy kulturowe i społeczno-polityczne. Kyrgyzstan: kul'turnyje i social'no-politiczieskije probliemy, 335-347. Oficyna Wydawnicza ASPRA-JR w Warszawie.

Achmadżonow Szuchrat. Jest' li szans pobiedit' I. Karimowa na wyborach w Uzbiekistanie? Dodano Czerwiec 16, 2015. http://www.centrasia.ru/newsA.php?st=11914883 40.

Adamowski Janusz. 2001. Środki masowego przekazu. W Uzbekistan: historia - społeczeństwo - polityka, 161-164. Dom Wydawniczy Elipsa w Warszawie.

Ambasada Rzeczypospolitej Polskiej w Taszkencie. Wybory prezydenckie w Republice Uzbekistanu. Dodano Lipiec 4, 2015. http://www.taszkent.msz.gov.pl/pl/c/MOBIL E/ aktualnosci/00015_04_01_wybory_prezydenta_ru.

Antoszewski Andrzej, Ryszard Herbut. 2007. Systemy polityczne współczesnej Europy. Warszawa: Wydawnictwo Naukowe PWN.

Bielewicz Antoni. Isłam Karimow: najbardziej krwawy z satrapów. Dodano Październik 28, 2015. http://www.psz.pl/117-polityka/islam-karimow-najbardziej-krwawy-sposrod-satrapow.

Bodio Tadeusz, Piotr Załęski. 2008. Elity władzy w Azji Centralnej: tradycja - modernizacja - etnopolityka. Warszawa: Dom Wydawniczy Elipsa.

Bodio Tadeusz, Tadeusz Mołdawa. 2007. Konstytucje państw Azji Centralnej: tradycje i współczesność. Warszawa: Dom Wydawniczy Elipsa w Warszawie.

Bodio Tadeusz. 2008. Układy klanowe jako mechanizm polityki (na przykładzie państw Azji Centralnej). W Transformacja społeczeństwa i władzy w postradzieckiej Azji Centralnej: studia i rozprawy, 152-162. Wydawnictwo Akademii Humanistycznej im. Aleksandra Gieysztora w Pułtusku.

Capisani Giampaolo R. 2004. Nowe państwa Azji Środkowej, Warszawa: Wydawnictwo Akademickie Dialog.

Dziemidok-Olszewska Bożena. 2003. Instytucja prezydenta w państwach Europy Środkowej i Wschodniej. Lublin: Wydawnictwo Marii Curie-Skłodowskiej.

Karimow Isłam. 2001. Uzbekistan na progu XXI wieku. Warszawa: Dom Wydawniczy Elipsa. 
Marciniak Ewa. 2001. Kompetencje przywódcy politycznego. W Przywództwo polityczne, 98-109, Dom Wydawniczy Elipsa w Warszawie.

Oficjalna strona internetowa Senatu Olij Madżlisu Republiki Uzbekistanu. Istorija razwitija parłamientarizma w Uzbiekistanie. Dodano Czerwiec 14, 2015. http://www.senat.uz/ru/about/index.html.

Priess-Służba Priezidienta Riespubliki Uzbiekistan. Biografija. Dodano Czerwiec 11, 2015. http:// www.press-service.uz/\#ru/content/glava_gosudarstwa/biografiya/.

L. Roszyk, Transformacja uzbecka: przełom czy kontynuacja. W Uzbekistan: historia - społeczeństwo - polityka, 175-176. Dom Wydawniczy Elipsa w Warszawie.

Saidov Akmal Kch., Konstanty Adam Wojtaszczyk. 2001. Konstytucyjne podstawy ustroju państwa. W Uzbekistan: historia - społeczeństwo - polityka, 129. Dom Wydawniczy Elipsa w Warszawie.

Sajnog Miłosz. 2007. Republika Uzbekistanu. W Ustroje polityczne krajów Wspólnoty Niepodległych Państw, 310-311. Wydawnictwo Uniwersytetu Wrocławskiego.

Szukalski Jerzy. 2014. System konstytucyjny Uzbekistanu. Warszawa: Wydawnictwo Sejmowe.

Szymanek Jarosław. 2010. Systemy rządów w krajach WNP: metodologia badań ustrojowo-porównawczych. W Przywództwo, elity i transformacje w krajach WNP, 247-250, 262-275. Oficyna Wydawnicza ASPRA-JR w Warszawie.

Turska-Kawa Agnieszka. 2013. Przywództwo polityczne jako wynik wzajemnej relacji między przywódcą a jego zwolennikami. W Przywództwo polityczne w Polsce i na świecie, 55-71. Wydawnictwo Uniwersytetu Warmińsko-Mazurskiego w Olsztynie.

Wiatr Jerzy. 2008. Przywództwo polityczne: studium politologiczne, Łódź: Wydawnictwo Akademii Humanistyczno-Ekonomicznej.

Załęski Piotr. 2011. Kultura polityczna więzi w Azji Centralnej. Warszawa: Oficyna Wydawnicza ASPRA-JR.

Załęski Piotr. 2008. Regionalizm, klientelizm i klanowość jako podstawy kultury politycznej w Uzbekistanie. W Transformacja społeczeństwa i władzy w postradzieckiej Azji Centralnej: studia i rozprawy, 281-285. Wydawnictwo Akademii Humanistycznej im. Aleksandra Gieysztora w Pułtusku.

Zamarajewa Aleksandra. 2008. Masakra w Andiżanie - między biedą, dyktaturą a rywalizacją klanową. W Transformacja społeczeństwa i władzy w postradzieckiej Azji Centralnej: studia i rozprawy, 105-119. Wydawnictwo Akademii Humanistycznej im. Aleksandra Gieysztora w Pułtusku.

Zapaśnik Stanisław. 2006. „Walczący islam” w Azji Centralnej, Wrocław: Wydawnictwo Uniwersytetu Wrocławskiego.

Zieliński Eugeniusz. 2005. Prezydent Federalny. W System polityczny Republiki Federalnej Niemiec, 103. Dom wydawniczy Elipsa w Warszawie.

Żukiewicz Przemysław. 2013. Instytucja prezydenta czy przywództwo prezydenckie - próba rozstrzygnięcia dylematu. W Przywództwo polityczne w Polsce i na świecie, 86-87. Wydawnictwo Uniwersytetu Warmińsko-Mazurskiego w Olsztynie.

Żukiewicz Przemysław. 2011. Przywództwo polityczne: teoria i praktyka. Warszawa: Wydawnictwo Difin. 


\section{THE EVOLUTION OF THE POSITION OF PRESIDENT OF UZBEKISTAN IN THE PERIOD BETWEEN 1990 AND 2015}

The institution of the president of Uzbekistan was established by the revision of the Constitution of Uzbek SRR from March 24th, 1990. Initially the president exercised typical functions of the head of state. The constitutional position of the president was significantly strengthened by the Constitution of Uzbekistan from December 8th, 1992, which gave him powers both as head of state and head of government. Although the constitutional revision accepted on April 11th, 2007 deprived the president of the position of the head of government, it did not have any great impact on maintaining his present strong constitutional position. Apart from the wide scope of his competence the significant indication of the president's constitutional position is the fact that he may not be removed from office before expiry of a current term. Thanks to this, he is actually neither politically nor constitutionally responsible. The evolution of the constitutional position of the president was influenced by the personality and pragmatism of actions of Islam Karimov, who has now been the President for over 25 years. He has managed to create a de facto authoritarian system in Uzbekistan, though formally under the guise of democracy.

Keywords: Uzbekistan, president, constitution, constitutional position, competence

Słowa kluczowe: Uzbekistan, konstytucja, pozycja ustrojowa, kompetencje 